\title{
MODEL MANAJEMEN MTS NU BANAT KUDUS DALAM MENINGKATKAN MUTU PENDIDIKAN ISLAM
}

\author{
Nailissa'adah \\ Program Studi Manajemen Pendidikan Islam STAIN Kudus \\ Jln. Kedungdowo 4/ 6 Kaliwungu Kudus, 59361, Indonesia \\ Email: nailissaadah_bintaafif@yahoo.co.id
}

DOI: $10.29313 /$ tjpi.v6i2.3186

Accepted: November 8th, 2017. Approved: January 18th, 2017. Published: January 18th, 2017

\begin{abstract}
This research answers: (1) How can governance of MTs NU Banat Kudus?; (2) How does the strategy of increasing the quality of Islamic education in MTs NU Banat Kudus?; and (3) How does the management model of MTs NU Banat Kudus in enhancing the quality of Islamic education? This research is a field research with a qualitative approach by interviews, observation and documentation. Analysis of data using model analysis Miles and Huberman by step data collection, data reduction and data display, then the conclusion and verification. The results showed that: 1) the governance of MTs NU Banat Kudus are buman resources management, student affairs, curriculum, facilities, finance, administration and public relations; 2) The strategies are developed the professionalism of teachers and employees, additional hour, open class dormitory, complete learning facilities, streamline coordination, cooperation, provide reinforcement religiosity, maintaining environmental conduciveness and held a debriefing after study. 3) The management model of MTs NU Banat Kudus is TQM model with emphasis on customer satisfaction, continue to make improvements that are sustainable, obsessed on the quality, the teamwork, optimizing the role of leader and always empowering employees.
\end{abstract}

Keywords: Management Model, Islamic Education Quality.

\section{ABSTRAK}

Rumusan masalah penelitian ini: (1) Bagaimana tata kelola MTs NU Banat Kudus?; (2) Bagaimana strategi peningkatan mutu pendidikan Islam di MTs NU Banat Kudus?; dan (3) Bagaimana model manajemen MTs NU Banat Kudus dalam meningkatkan mutu pendidikan Islam? Penelitian ini adalah penelitian lapangan kualitatif. Data dikumpulkan melalui wawancara, observasi dan dokumentasi. Analisis data dengan model Miles and Huberman dari pengumpulan data, reduksi data, display data serta kesimpulan dan verifikasi. Hasil penelitian: 1) tata kelola MTs NU Banat Kudus yaitu manajemen SDM, kesiswaan, kurikulum, sarana prasarana, keuangan, ketatausahaan, dan humas; 2) Strateginya dengan mengembangkan profesionalisme guru/karyawan, jam tambahan, kelas asrama, melengkapi fasilitas, koordinasi, kerjasama, religiusisme, mengkondusifkan lingkungan, dan pendidikan pascabelajar; 3) Model manajemennya model Total Quality Management (TQM) mengutamakan kepuasan pelanggan, perbaikan berkesinambungan, berobsesi kualitas, kerjasama tim, mengoptimalkan kepemimpinan serta memberdayakan karyawan.

Kata Kunci: Model Manajemen, Mutu Pendidikan Islam. 


\section{PENDAHULUAN}

Syafaruddin menyebutkan dalam bukunya yang berjudul "Manajemen Mutu Terpadu dalam Pendidikan Konsep, Strategi dan Aplikasi" bahwa terdapat beberapa faktor yang menyebabkan rendahnya mutu pendidikan. Faktor internal adalah kurikulum, sumber daya ketenagaan, kepemimpinan, sarana dan fasilitas, manajemen sekolah dan pembiayaan pendidikan. Faktor eksternal yang mempengaruhi antara lain ekonomi yang tidak berpihak terhadap pendidikan, sosial budaya serta rendahnya penguasaan sains dan teknologi. Faktor-faktor tersebut harus dikelola dan diminimalisasi agar tidak menjadi penghambat tercapainya mutu pendidikan (Syafaruddin, 2002: 14).

Sistem pendidikan meliputi input, proses dan output. Apabila semua unsur atau komponen pendidikan berfungsi dan berinteraksi secara baik, maka akan dapat mencapai tujuan pendidikan yang dicitacitakan. Sumber daya yang dimiliki diproses dengan cara-cara tertentu sehingga dapat menghasilkan keluaran atau lulusan yang bermutu. Lulusan yang bermutu merupakan sumber daya manusia yang dihasilkan dari sekolah yang bermutu (Syafaruddin, 2005: 24).

Salah satu unsur yang berperan dalam proses peningkatan mutu pendidikan adalah lembaga pendidikan karena sebagai pelaksana pendidikan. Upaya peningkatan mutu lembaga pendidikan memerlukan peran aktif dan partisipasi dari semua pihak baik Pemerintah, warga sekolah, orang tua siswa, tokoh agama serta seluruh masyarakat. Upaya lain yang dilakukan untuk mewujudkan lembaga pendidikan yang representatif bagi masyarakat adalah dengan diterapkannya manajemen lembaga pendidikan yang efektif dan efisien (Ula, 2013: 174). Dengan demikian, sebuah lembaga pendidikan harus dikelola dengan manajemen yang tepat agar dapat menghasilkan lulusan yang berkualitas, tidak terkecuali lembaga pendidikan Islam.
MTs NU Banat Kudus sebagai sebuah lembaga pendidikan Islam yang berada di bawah naungan BPPM NU Banat Kudus memiliki visi untuk mewujudkan madrasah putri sebagai pusat keunggulan yang mampu menyiapkan dan mengembangkan sumber daya manusia yang berkualitas di bidang IMTAQ dan IPTEK yang Islami dan Sunni (Profil MTs NU Banat Kudus Tahun Pelajaran 2014/2015). Melalui visi tersebut maka MTs NU Banat Kudus berkomitmen untuk mendirikan sekolah berbasis agama khusus wanita yang berhaluan Ahlu Sunah Waljama'ah dan diperuntukkan khusus bagi kaum wanita.

Tujuan MTs NU Banat Kudus tidak dapat tercapai apabila dalam pengelolaan lembaganya tidak memakai konsep manajemen yang profesional, efektif dan efisien. Penelitian ini bermaksud untuk meneliti model manajemen MTs NU Banat Kudus dalam meningkatkan mutu pendidikan Islam.

Rumusan masalah dalam penelitian ini yaitu: 1) Bagaimana tata kelola MTs NU Banat Kudus?; 2) Bagaimana strategi peningkatan mutu pendidikan Islam di MTs NU Banat Kudus?; 3) Bagaimana model manajemen MTs NU Banat Kudus dalam meningkatkan mutu pendidikan Islam?

\section{METODOLOGI PENELITIAN}

Penelitian ini merupakan penelitian lapangan dengan pendekatan kualitatif yaitu menekankan analisisnya pada proses penyimpulan induktif serta pada analisis terhadap dinamika hubungan antar fenomena yang diamati dan dengan menggunakan logika ilmiah (Mahmud, 2011: 81). Penelitian ini menggunakan desain deskriptif dan grounded research. Desain deskriptif merupakan upaya untuk mengamati permasalahan secara sistematis dan akurat mengenai fakta dan sifat objek tertentu. Adapun desain grounded merupakan kebalikan dari penelitian ex post facto sehingga bertolak dari fakta untuk 
diwujudkan dalam sebuah teori (Mahmud, 2011: 81). Berawal dari penjabaran tentang tata kelola serta strategi yang dilakukan oleh MTs NU Banat Kudus dalam meningkatkan mutu pendidikan Islam maka ditarik sebuah kesimpulan tentang model manajemen yang diterapkan.

Data dalam penelitian ini diperoleh dengan menggunakan teknik wawancara, observasi dan dokumentasi. Wawancara dilakukan terhadap Ketua BPPM NU Banat, Wakil Ketua BPPM NU Banat, Sekretaris BPPM NU Banat, Wakil Bendahara BPPM NU Banat, Seksi Pendidikan dan Pengajaran BPPM NU Banat, Seksi Humas BPPM NU Banat, Kepala MTs NU Banat, Wakil Kepala Bagian Kurikulum, Waka Kesiswaan, Waka Sarpras, Guru MTs NU Banat, peserta didik serta wali murid MTs NU Banat Kudus. Observasi terhadap pelaksanaan koordinasi dan pembinaan Ahad awal dan akhir bulan serta pada saat pendaftaran peserta didik baru. Studi dokumentasi terhadap dokumen-dokumen resmi yang diperoleh dari MTs NU Banat Kudus.

Analisis data penelitian ini menggunakan analisis data model Miles and Huberman melalui pengumpulan data (data collection), reduksi data (data reduction), display data (data display) serta konklusi dan verifikasi (conclution and verification) (Sugiyono, 2007: 338). Uji keabsahan data dalam penelitian ini mengacu pada aspek kredibilitas dengan perpanjangan pengamatan, meningkatkan ketekunan, triangulasi, menggunakan bahan referensi serta mengadakan member check. Selain itu mengacu pada aspek transferabilitas, dependabilitas dan konfirmabilitas (Sugiyono, 2007: 369).

\section{PEMBAHASAN}

\section{Tata Kelola MTs NU Banat Kudus}

Tata Kelola MTs NU Banat Kudus meliputi: a) Manajemen SDM dimulai dari perekrutan guru dan karyawan melalui
BPPM NU Banat dan Kepala MTs NU Banat; b) Manajemen kesiswaan dalam menerima peserta didik terdapat tes seleksi penerimaan peserta didik baru dan penempatan peserta didik secara homogen dan heterogen di kelas asrama dan kelas reguler; c) Manajemen kurikulum dimulai dari perencanaan pada saat rapat kerja, pengorganisasian, pelaksanaan dan evaluasi dengan menerapkan kurikulum tingkat satuan pendidikan (KTSP) dan kurikulum 2013, kurikulum muatan lokal serta kegiatan ekstrakurikuler; d) Manajemen sarana prasarana dimulai dari perencanaan, pengajuan anggaran, pembelian serta inventarisasi di buku inventaris dan pemberian label inventaris; e) Manajemen keuangan dengan membuat RAPBM setiap tahun untuk diajukan ke BPPM NU Banat. Bendahara Madrasah melaporkan kepada Bendahara BPPM NU Banat secara harian, bulanan dan tahunan. Dana berasal dari Pemerintah dan swadaya masyarakat (wali murid); f) Manajemen ketatausahaan terkait dengan pembuatan dan penerimaan surat masuk dan surat keluar yang merupakan wewenang bagian tata usaha; g) Manajemen hubungan kemasyarakatan dengan menjalankan prinsip ABG (academic, bussinessman and government) yaitu menjalin kerjasama dengan pihak Pemerintah dan instansi swasta.

Manajemen sumber daya manusia di MTs NU Banat Kudus sesuai dengan salah satu sistem perekrutan tenaga pendidik dan kependidikan yang disampaikan oleh Sondang P. Siagian. Menurutnya, pelaksanaan manajemen sumber daya manusia dimulai dari proses rekrutmen tenaga kerja yang ada kalanya pelamar datang sendiri ke lokasi tanpa mengetahui apakah lembaga tersebut membuka lowongan atau tidak. Selain itu juga dapat diperoleh informasi dari orang dalam, diiklankan di media massa atau melalui instansi Pemerintah (Siagian, 1996: 112).

Manajemen kesiswaan di MTs NU Banat Kudus terbagi ke dalam tiga tahap yaitu penjaringan, pemrosesan, dan 
pendistribusian. Tahap penjaringan dimulai dari promosi terkait dengan penerimaan peserta didik baru yang diinformasikan melalui brosur dan website Madrasah. Selain itu juga terdapat pelaksanaan seleksi melalui tes untuk mengetahui kualitas calon peserta didik baru. Terkait dengan tahap pembelajaran terdapat kegiatan ko-kurikuler dan ekstrakurikuler serta kurikulum pengayaan/jam tambahan di MTs NU Banat Kudus. hal ini sesuai dengan pendapat Mujamil Qomar bahwa pengembangan potensi siswa tidak hanya menyangkut ranah kognitif saja tetapi juga afektif dan psikomotorik bahkan metakognitif (Qomar, 2007: 144). Guruguru juga menerapkan beberapa metode dalam proses pembelajaran sehingga tidak hanya model ceramah saja tetapi dengan metode diskusi dan tanya jawab serta disediakan proyektor LCD untuk menyampaikan materi pelajaran. Ditinjau dari segi pendistribusian atau persiapan studi lanjut, MTs NU Banat Kudus juga memberikan pembekalan pada peserta didik yang hendak lulus sebagai pendidikan pascabelajar.

Kurikulum MTs NU Banat Kudus mengacu pada Kurikulum Tingkat Satuan Pendidikan (KTSP) untuk kelas IX dan VIII serta Kurikulum 2013 untuk kelas VII. Hal ini sesuai dengan muatan kurikulum 2013 yang disusun berdasarkan Permenag RI Nomor 000912 Tahun 2013 tentang Kurikulum Madrasah 2013. Sedangkan muatan Kurikulum KTSP berdasarkan pada UU RI Nomor 20 Tahun 2003 tentang Sistem Pendidikan Nasional dan PP RI Nomor 32 Tahun 2013 tentang Standar Nasional Pendidikan.

Keberadaan sarana dan prasarana di MTs NU Banat Kudus sesuai dengan pendapat Mujamil Qomar yang menyatakan bahwa keberadaan sarana pendidikan merupakan hal mutlak dibutuhkan dalam proses pendidikan. Tanpa sarana pendidikan maka proses pendidikan akan mengalami kesulitan bahkan dapat menggagalkan pendidikan (Qomar, 2007: 170).

Manajemen keuangan MTs NU Banat Kudus sesuai dengan pendapat Jones yang dikutip oleh Mulyasa meliputi tiga fase, yaitu: financial planning, implementation involves accounting dan evaluation involves (Mulyasa, 2012: 48) Fase perencanaan dimulai dari penyusunan RAPBM. Fase implementasi berupa penggunaan anggaran untuk kegiatan rutin seperti gaji dan biaya operasional serta anggaran untuk pengembangan Madrasah. Fase evaluasi dengan pelaporan keuangan kepada Bendahara BPPM NU Banat Kudus secara harian, bulanan maupun tahunan.

Manajemen ketatausahaan MTs NU

Banat Kudus sesuai penjelasan B. Suryosubroto bahwa kegiatan ketatausahaan meliputi pengurusan surat dinas sekolah dan buku agenda, buku ekspedisi dan buku catatan rapat sekolah (Suryosubroto, 2010: 104).

MTs NU Banat Kudus yang menerapkan prinsip ABG (academic, bussinessman and government) sesuai dengan pendapat Ngalim Purwanto yang dikutip oleh B. Suryosubroto bahwa hubungan sekolah dengan masyarakat meliputi hubungan sekolah dengan sekolah lain, sekolah dengan Pemerintah, sekolah dengan instansi/jawatan lain, serta sekolah dengan masyarakat pada umumnya (Suryosubroto, 2010: 160).

\section{Strategi Peningkatan Mutu Pendidikan Islam di MTs NU Banat Kudus}

MTs NU Banat Kudus memiliki beberapa strategi sebagai upaya untuk meningkatkan mutu pendidikan Islam. Strategi tersebut yaitu: a) Mengembangkan profesionalisme guru dan karyawan melalui kegiatan workshop/pelatihan serta melanjutkan pendidikan ke jenjang yang lebih tinggi; b) Meningkatkan mutu peserta didik melalui kegiatan ekstrakurikuler dan pemberian jam tambahan sebagai kurikulum pengayaan; c) Pembuatan kelas asrama 
diperuntukkan bagi peserta didik yang berada di peringkat 40 besar pada saat tes seleksi masuk; d) Pemenuhan sarana prasarana dengan menyediakan layar LCD di setiap kelas, microphone serta jaringan internet (Wifi); e) Mengefektifkan koordinasi yang diselenggarakan setiap hari Ahad di awal dan akhir bulan bersama dengan BPPM NU Banat serta setiap hari Senin (Rapat Senin-an) di lingkungan internal MTs NU Banat Kudus; f) Menjalin kerjasama dengan berbagai pihak Pemerintah maupun swasta karena menerapkan prinsip ABG (academic, bussinessman and government); g) Memberikan penguatan religiusitas melalui pembiasaan istighasah, shalat dhuhur berjama'ah serta penyusunan Qanun Asasi bagi guru dan karyawan; h) Kondusifitas lingkungan dengan berprinsip pada $9 \mathrm{~K}$ yaitu keimanan, kebersihan, keamanan, ketertiban, keindahan, kekeluargaan, kerindangan, kesehatan dan kepusatakaan; i) Memberikan pendidikan pascabelajar yaitu berupa pembekalan tentang penguatan ajaran Aswaja.

Pengembangan profesionalisme guru dan karyawan terkait dengan kompetensi akademik yang perlu dimiliki oleh para guru adalah kompetensi akademik, kepribadian, sosial, dan profesional. Hal ini seperti pendapat Shapero yang dikutip oleh Mujamil Qomar bahwa manajemen pegawai yang profesional melalui how to have dan how to empower (Qomar, 2007: 134). How to have melalui penerimaan lamaran kepada Kepala MTs NU Banat Kudus maupun kepada BPPM NU Banat Kudus, sedangkan how to empower melalui pelatihan dan melanjutkan pendidikan.

Peningkatan mutu peserta didik sesuai dengan Mulyasa bahwa pada dasarnya tujuan pendidikan tidak hanya untuk mengembangkan aspek kognitif peserta didik saja tetapi juga aspek afektif atau kepribadian, sosial emosional serta ketrampilan lain (Mulyasa, 2012: 47).
Pembuatan kelas asrama sesuai dengan pendapat Mujamil Qomar bahwa dalam tahap proses pembelajaran setelah siswa resmi diterima maka tahap selanjutnya adalah pengelompokan siswa dapat secara homogen maupun heterogen (Qomar, 2007: 145).

Pemenuhan sarana prasarana MTs NU Banat Kudus selalu mengikuti perkembangan zaman dalam bidang teknologi. Hal tersebut sangat mendukung pencapaian kualitas Madrasah.

Pengefektifan koordinasi di MTs NU Banat Kudus sesuai dengan konsep TQM bahwa salah satu unsur acuan untuk mencapai pada mutu adalah dengan memperbaiki proses secara berkesinambungan (Ula, 2013: 46).

Jaringan kerjasama yang dijalin oleh MTs NU Banat Kudus harus lebih ditingkatkan untuk meningkatkan kualitas pendidikan semisal dengan mengadakan seminar atau workshop.

Penguatan religiusitas yang dikembangkan MTs NU Banat Kudus seyogyanya tidak hanya sekedar sebagai rutinitas saja tetapi juga harus dapat diaplikasikan dalam kehidupan sehari-hari yang terwujud dari perilakunya. Tidak hanya menjaga hubungan baik dengan Tuhan (bablun min Allab) tetapi juga hubungan baik dengan sesama manusia (bablun min an-nas).

Kondusifitas lingkungan di MTs NU Banat Kudus searah dengan pendapat Mujamil Qomar bahwa penataan lingkungan dalam kompleks lembaga pendidikan Islam harus rapi, indah, bersih, anggun dan asri (Qomar, 2007: 172).

Pendidikan pasca belajar yang diselenggarakan di MTs NU Banat Kudus mencirikan sebagai salah satu indikator sekolah efektif. Sebagaimana dijelaskan oleh S. Shoimatul Ula bahwa salah satu cara untuk menempuh sekolah efektif adalah dengan adanya persiapan studi lanjut (Ula, 2013: 88). Tetapi pelaksanaannya harus lebih ditingkatkan. 
Model Manajemen MTs NU Banat Kudus dalam Meningkatkan Mutu Pendidikan Islam

Berdasarkan pada tata kelola serta strategi yang dilakukan oleh MTs NU Banat Kudus maka dapat diketahui bahwa model manajemen yang diterapkan MTs NU Banat Kudus adalah model Total Quality Management (TQM). Hal tersebut dapat ditinjau dari beberapa segi sebagai karakteristik dari manajemen TQM, yaitu: a) Mengutamakan kepuasan pelanggan baik pelanggan internal (guru/karyawan dan peserta didik) dan pelanggan eksternal (wali murid dan pengguna jasa pendidikan); b) Melakukan perbaikan yang berkesinambungan yaitu dengan mengefektifkan koordinasi; c) Berobsesi pada kualitas dengan mengutamakan mutu pada input, proses dan output dalam segala bidang manajemen; d) Adanya kerjasama tim (teamwork) yang tampak dari adanya pembagian kerja melalui koordinator bidang; e) Mengoptimalkan peran kepemimpinan baik kepemimpinan dari BPPM NU Banat dan Kepala MTs NU Banat; f) Memberdayakan karyawan yang terlihat dari adanya pemberian tugas dan tanggung jawab untuk masing-masing guru/karyawan.

MTs NU Banat Kudus mengutamakan kepuasan pelanggannya dimulai dari penyusunan Visi dan Misi Madrasah untuk menyiapkan sumber daya manusia yang berkualitas di bidang keimanan dan takwa serta ilmu pengetahuan dan teknologi. Begitu juga pada saat proses pembelajaran berlangsung juga selalu mengutamakan kepuasan guru, karyawan dan peserta didiknya dilihat dari strategi yang dilakukannya. Hal ini sejalan dengan pendapat W. Edwards Deming bahwa untuk memenuhi kebutuhan pelanggan maka perlu memperhatikan Siklus Deming mulai dari mengadakan riset konsumen (plan), menghasilkan produk (do), memeriksa produk apakah sudah sesuai dengan rencana (check), memasarkan produk (act), menganalisis bagaimana produk diterima di pasar (analyze). Dengan demikian selalu diperhatikan kepuasan pelanggannya (Tjiptono dan Diana, 2003: 50).

MTs NU Banat Kudus selalu melakukan koordinasi baik secara internal maupun eksternal. Hal ini menunjukkan bahwa MTs NU Banat Kudus selalu melakukan perbaikan yang berujung pada pengutamaan kepuasan pelanggan. Sebagaimana yang disampaikan oleh Joseph M. Juran dalam Juran's Three Basic Steps to Progress bahwa apabila hendak mencapai kelas dunia maka perusahaan harus melakukan perbaikan terstruktur atas dasar kesinambungan (Tjiptono dan Diana, 2003: 53).

MTs NU Banat Kudus memiliki Visi terwujudnya Madrasah putri sebagai pusat keunggulan. Apabila ditinjau dari Visi tersebut maka diapat diketahui bahwa MTs NU Banat Kudus memiliki harapan dan berobsesi untuk menjadi Madrasah yang memiliki kualitas unggul dibandingkan madrasah lainnya. Menurut Joseph M. Juran bahwa suatu produk atau jasa dikatakan bermutu/berkualitas apabila dapat memenuhi harapan para pemakainya (Tjiptono dan Diana, 2003: 53).

MTs NU Banat Kudus membagi susunan kerja ke dalam beberapa bagian yang masing-masing terdapat koordinator bidang. Hal tersebut menunjukkan bahwa tidak ada prinsip persaingan dalam unsurunsur tersebut karena semua bekerja secara solid. Adanya kerjasama tim tersebut sesuai dengan pendapat Deming dalam Deming's Fourteen Points yang salah satu poinnya menyebutkan untuk menghilangkan dinding pemisah antar departemen sehingga orang dapat bekerja sebagai suatu tim (Tjiptono dan Diana, 2003: 51).

Kepemimpinan di MTs NU Banat Kudus tidak hanya terlihat dari top manajemen yang berada di tangan Kepala Madrasah saja tetapi juga dari kepemimpinan masing-masing koordinator. Arah kepemimpinan tersebut sebagaimana yang dikatakan oleh Deming bahwa tujuan 
dari kepemimpinan haruslah untuk membantu orang dan teknologi dapat bekerja dengan lebih baik (Tjiptono dan Diana, 2003: 51).

Adanya kerjasama tim dalam struktur pembagian kerja di MTs NU Banat Kudus menunjukkan adanya pemberian tanggung jawab kepada seluruh komponen Masyarakat. Adanya pembagian kerja tersebut sesuai dengan pendapat W. Edward Deming bahwa untuk menuju pada suatu perusahaan berkelas dunia maka harus menghapus rasa takut sehingga setiap orang dapat bekerja secara efektif (Tjiptono dan Diana, 2003: 51).

\section{KESIMPULAN}

Model manajemen yang diterapkan MTs NU Banat Kudus adalah model Total Quality Management (TQM). Melalui model TQM tersebut, MTs NU Banat Kudus selalu mengutamakan kepuasan pelanggan dengan terus melakukan perbaikan secara berkesinambungan untuk memperoleh mutu/kualitas yang unggul. Tata kelola MTs NU Banat Kudus meliputi manajemen sumber daya manusia, kesiswaan, kurikulum, sarana prasarana, keuangan, ketatausahaan, dan humas. Strategi yang digunakan adalah selalu mengembangkan profesionalisme tenaga pendidik dan kependidikan serta pemenuhan sarana dan prasarana. Selain itu juga selalu menjaga kondusivitas lingkungan belajar serta adanya pembekalan pascabelajar untuk calon alumni.

\section{DAFTAR PUSTAKA}

Amtu, Onisimus. (2011). Manajemen Pendidikan di Era Otonomi Daerab; Konsep, Strategi dan Implementasi. Bandung: Alfabeta.

Athoillah, M. Anton. (2010). Dasar-dasar Manajemen. Bandung: Pustaka Setia.

Baharuddin dan Umiarso. (2012). Kepemimpinan Pendidikan Islam; antara
Teori \& Praktik. Jogjakarta: Ar-Ruzz Media.

Danim, Sudarwan. (2008). Visi Baru Manajemen Sekolah; dari Unit Birokrasi ke Lembaga Akademik. Jakarta: Bumi Aksara.

Fattah, Nanang. (2013). Sistem Penjaminan Mutu Pendidikan. Bandung: Remaja Rosdakarya.

Kisbiyanto. (2011). Manajemen Pendidikan; Pendekatan Teoritik \& Praktik. Yogyakarta: Ide Press.

Mahmud. (2011). Metode Penelitian Pendidikan. Bandung: Pustaka Setia.

Mulyasa, E. (2003). Manajemen Berbasis Sekolah. Bandung: Remaja Rosdakarya. (2012). Manajemen dan Kepemimpinan Kepala Sekolah. Jakarta: Bumi

Qomar, Mujamil. (2007). Manajemen Pendidikan Islam; Strategi Baru Pengelolaan Lembaga Pendidikan Islam. Jakarta: Erlangga.

Rusman. (2008). Manajemen Kurikulum. Bandung: Rajawali Pers.

Siagian, Sondang P. (1996). Manajemen Sumber Daya Manusia. Jakarta: Bumi Aksara.

Soegito, A.T. (2013). Pergeseran Paradigmatik Manajemen Pendidikan. Semarang: Widya Karya.

Sugiyono. (2007). Metode Penelitian Pendidikan (Pendekatan Kuantitatif, Kualitatif, dan R\&D). Bandung: Alfabeta.

Suryosubroto, B. (2010). Manajemen Pendidikan di Sekolah. Jakarta: Rineka Cipta.

Sutikno, M. Sobry. (2012). Manajemen Pendidikan; Langkah Praktis Mewnjudkan Lembaga Pendidikan yang Unggul (Tinjauan Umum dan Islami). Lombok: Holistica.

Syafaruddin. (2002). Manajemen Mutu Terpadu dalam Pendidikan Konsep, Strategi dan Aplikasi. Jakarta: Grasindo. (2005). Manajemen Lembaga Pendidikan Islam. Jakarta: Ciputat Press. 
Syukur, Fatah. (2011). Model Manajemen Madrasah Aliyah Efektif (Studi pada Tiga Madrasah Aliyah di Kudus). Disertasi pada Program Studi Manajemen Pendidikan, Program Pascasarjana Universitas Negeri Semarang.

Tjiptono, Fandy dan Anastasia Diana. (2003). Total Quality Management. Yogyakarta: ANDI.

Ula, S. Shoimatul. (2013). Buku Pintar Teoriteori Manajemen Pendidikan Efektif. Jogjakarta: Berlian.

Profil MTs NU Banat Kudus Tahun Pelajaran 2014/2015. 